\title{
LEGAL CERTAINTY OF LAND TITLE IN FACILITATING FOREIGN DIRECT INVESTMENT IN ACEH PROVINCE, INDONESIA
}

\author{
Dina Luqyana \\ Faculty of Law, Syiah Kuala University, Indonesia \\ J1. Putroe Phang No. 1 Darussalam, Banda Aceh, 23111 \\ Tel./Fax: +62-651-7552295 e-mail : dinaaluqyana@gmail.com \\ Azhari Yahya \\ Faculty of Law, Syiah Kuala University, Indonesia \\ Jl. Putroe Phang No. 1 Darussalam, Banda Aceh, 23111 \\ Tel./Fax: +62-651-7552295 e-mail : azhari.yahya@unsyiah.ac.id
}

\begin{abstract}
Law Number 25 Year 2007 on Capital Investment facilitates services and/or licensing of Land Rights to Use for investment. Article 22(a) stipulated that land Rights to Use (HGB) can be granted up to 95 years for land cultivation rights, up to 160 years for building use rights, and up to 140 years for land Rights to Use. However, land Rights to Use regulated in Qanun Number 14 Year 2017 on Aceh's Assets Management is only five years subject to certain conditions and requirements for extension. It is clear that there two legislations available in Aceh in terms of facilitating land license for investment. Therefore, a research question raised is which law is applied by the Government of Aceh to speed the process of land license for the investor? This study uses normative legal research by relying on primary and secondary legal resources. Primary legal resources were collected by analyzing related legislations, while secondary legal resources were obtained by reviewing associated literature. The result shows that in facilitating land license for investors in Aceh, the Government of Aceh applies Qanun Number 14 Year 2017 on Aceh's Assets Management instead of Law Number 25 Year 2007 on Capital Investment. This Qanun stipulated that land license for investors is given for five years with specific requirements for extension. This short period for a land license causes legal uncertainty for investors and decreases their motivation to invest in Aceh Province. It is suggested that this Qanun should be amended to be in line with national legislation, namely law Number 25 Year 2007 that provides a longer period of land license for investors.
\end{abstract}

Keywords: Legal certainty; Land license; Foreign Direct Investment.

\section{A. INTRODUCTION}

Foreign direct investment (FDI) can be a crucial source for capital enhancement in a state. ${ }^{1}$ FDI can also produce domestic investment in matching funds, facilitating the transfer of managerial skills and increasing market competition. ${ }^{2}$ Developed countries have the highest level of FDI inflows so that they have higher export productivity factors than

\footnotetext{
${ }^{1}$ Cep Jandi Anwar, "Faktor-Faktor yang Mempengaruhi Foreign Direct Investment (FDI) di Kawasan Asia Tenggara.", Media Trend, Vol.11, No. 2, (2016), p 175.

2 Ylvije Kraja Boriçi and Elezi Osmani. "Foreign Direct Investment and Economic Growth in Albania", Economics, Vol 3, No. 2, (2015), p 27.
} 
developing countries with lower FDI inflows. ${ }^{3}$ Developing countries have considered FDI in previous years as one of the best ways to increase their economic growth. Meanwhile, developing countries have lack national savings, so that they have less investment ${ }^{4}$. Indonesia, as a developing country, requires significant funds to carry out economic development. There are at least two factors to attract investors: macroeconomic stability and a financial labor market. These factors have been identified in the literature as the most critical aspects that foreign investors analyze before investing in a host country. ${ }^{5}$

The Aceh government faces obstacles in increasing FDI inflows into the province. One of the significant obstacles is regulation. Indonesian Government provides foreign direct investment and domestic investment opportunities through Law Number 25 Year 2007 on Capital Investment. However, Aceh also has Law Number 11 Year 2006 on Governance of Aceh, Qanun Number 5 Year 2018 on Capital Investment, and Qanun Number 14 Year 2017 on Aceh's Assets Management. The Qanun itself is a regulation similar to a regional law that regulates the administration of governance and community life in Aceh Province.

Law No. 25 of 2007 on Capital Investment facilitates services and/or licensing of the rights over the land as stipulated in Article 21(a). The Government provides ease of service and/or permits for investment companies to obtain the land title. Furthermore, the land title stipulated in Article 22 can be granted up to 95 years for Rights to Cultivate by granting it 60 (sixty) years initially and can be renewed for 35 (thirty-five) years. Then, for Right to Build, it can be given with an amount of 80 (eighty) years and can be extended in advance at once by 50 (fifty) years initially and can be renewed for 30 (thirty) years. For Right to Use, it can be granted in the amount of 70 (seventy) years and can be extended in advance at once by 45 (forty-five) years and can be renewed for 25 (twenty-five) years. However, the Government of Aceh provides land facilities for investors only for five years and can be extended as stated in article 62(1) of Qanun Number 14 Year 2017 about Aceh's Assets Management ${ }^{6}$. This condition is quite confusing for investors. They might be afraid to invest in Aceh due to the short term of the land license period as regulated by the Qanun Number 14 Year 2017. There are two legislations available in Aceh to facilitate land license for investment, namely Law

${ }^{3}$ Aurangzeb Zeb and Thanasis Stengos, "The Role of Foreign Direct Investment (FDI) in a Dualistic Growth Framework: An Application of Smooth Coefficient Semi-parametric Approach.", Borsa Instanbul Review, Vol.14, No.3, (2014), p 141.

4 Claudia TeziaJanuarita Putri and Regina Niken Wilantari, "Determinan Aliran Foreign Direct Investment di Indonesia (Pendekatan Model Dunning).", Media Trend, Vol. 11, No. 2, (2016), p 141.

5 V. Alecsandru Strat, Adriana Davidescu, and Andreea Maria Paul, "FDI and the unemployment-a causality analysis for the latest EU members.", Procedia economics and finance, Vol. 23, No. 2015, (2015), p 636.

${ }^{6}$ Qanun Number 14, Year 2017 about Aceh's good management 
Number 25 of 2007 on Capital Investment, as national legislation, and Qanun Number 14 Year 2017 on Aceh's Assets Management, as local legislation. That situation is a legal issue that needs to be scrutinized profoundly to find out a solution properly. Therefore, a research question that needs to be raised in this study is: which law is applied by the Government of Aceh in facilitating land license for investors investing in Aceh Province?

\section{B. RESEARCH METHODS}

The research method used in this study is normative legal research by analyzing related legislations and literature. Data required for this study are secondary data that were obtained from primary and secondary legal resources. Primary legal resources were collected by analyzing related legislation, while secondary legal resources were obtained by reviewing associated literature such as books, journal articles, government reports, magazines, etc. After all required data were collected, then those data were analyzed by using qualitative analysis.

\section{FINDINGS AND ANALYSIS}

Every economic activity needs legal support because without adequate legal support, and it may create an absence of legal certainty. At the same time, it may impact economic activity itself. Legal certainty can give confidence to every economic actor because they can easily predict the benefits they expect to get. If the profits are predictable with legal certainty, it will help investors to decide their investment. In economic activity, especially in investment, legal rules are often complained about, such as investment security issues, licensing procedure problems, law enforcement issues, labor issues, and soon. As a result, Indonesia is categorized as an uncomfortable place to invest. Whereas following the nature of risky investment activities, investment activities must be supported by a rule that can create certainty (predictability), fairness (justice), and efficiency (efficiency) ${ }^{7}$.

The principle of legal certainty is a form of protection for the seekers of justice against arbitrary actions, which means that a person will and can get something that is expected in certain circumstances. Legal certainty has two aspects: the determination of the law in concrete terms and legal security. It means that those who seek justice want to know what constitutes law in a specific matter before starting a case and protection for justice seekers. Without legal certainty, people do not know what to do. The legal system's indecisiveness will be uncertain, which will eventually lead to violence (chaos). Thus, legal

${ }^{7}$ Jaja Ahmad Jayus, "Konsep Sistem Hukum Investasi Dalam Menjamin Adanya Kepastian Hukum.", JURNAL LITIGASI (e-Journal), Vol. 6, No. 2, (2016), p 2907. 
certainty refers to a precise, consistent application of the law, where subjective conditions cannot influence the implementation ${ }^{8}$.

Therefore, if having legal certainty will open up the relationship between one country to another. As a result, it may create vast opportunities to develop pleasing cooperation in the future. Host countries realize that the implications that will arise with the presence of foreign investors in their countries are challenging to avoid. In this case, strong leadership from the state administrators is needed because the state requires capital in various forms of development. ${ }^{9}$ The capital referred here is not merely in the form of fresh funds but also includes skills, technology development, and human resources. So for investors to open themselves up, legal certainty is critical to be implemented.

According to Article 62(a) Qanun Number 14 Year 2017 on Aceh's Assets Management, someone can lease land in Aceh for 5 (five) years since the agreement is signed and extended for some period time. This stipulation is in line with the Regulation of the Minister of Home Affairs Decree Number 19 Year 2016, on the Guidelines for the Management of Regional Property Article 114: (1) The period of lease of goods belonging to the area is 5 (five) years since the signing of the agreement and can be extended. (2) The period of lease of goods belonging to the area as referred to in subsection (1) may be more than 5 (five) years and may be extended to:

a. Infrastructure cooperation;

b. Activities with business characteristics that require a lease term of more than 5 (five) years; or

c. Specified otherwise in the Act.

Specific regulations relating to the land use right for the investor in Indonesia:

1. Government Regulation of the Republic of Indonesia Number 28 of 2020 on The Amendments of Government Regulation Number 27 Year 2014 on Government's Assets Management. Article 29 stipulated that:

1) State/regional property can be leased to other parties.

2) The period for leasing state/regional property is no longer than 5 (five) years and can be extended.

3) The period for leasing state/regional property as meant in subsection (2) can be more than 5 (five) years and can be extended to:

${ }^{8}$ Mario Julyano and Aditya Yuli Sulistyawan, "Pemahaman Terhadap Asas Kepastian Hukum Melalui Konstruksi Penalaran Positivisme Hukum.", Jurnal Crepido, Vol. 1, No. 1, (2019), p 13-14.

${ }^{9}$ Sentosa Sembiring, Hukum Investasi, Bandung: Nuansa Aulia, 2007, p. 3. 
a) Infrastructure cooperation;

b) Activities with business characteristics requiring a lease period of more than 5 (five) years; or

c) Stated otherwise in the law.

2. Regulation of The Ministerial Decree of Finance of The Republic of Indonesia Number 144/Pmk.06/2020 On The Management of State-Owned Goods By The General Service Agency of The State Asset Management Institution

Article 17 of this regulation said that:

(1) The lease term may be carried out:

a. Maximum 5 (five) years and can be extended

b. More than 5 (five) years and a maximum of 50 (fifty) years, for Leasing Partners:

i. With an economic value that takes more than 5 (five) years; or

ii. It is stipulated otherwise in the laws and regulations.

Regardless of their citizenship status, everyone can have the land title so that foreigners and foreign legal entities can have the land title in Indonesia. This principle is reflected in Article 4(1) of Law Number 5 Year 1960 on the Basic Agrarian Principle. The difference only occurs in the type of land title that a person can have. A land title to foreigners for residential ownership is regulated in Indonesia's Government Regulation Number 103 Year 2015 on Ownership of Residential or Residential Houses by Foreigners Domiciled in Indonesia. Foreigners and Foreign Legal Entity (BHAs) having representatives in Indonesia can have a legal title called Right to Use as regulated in Article 41 to Article 43 the Law Number 5 Year 1960 on Basic Agrarian Principle.

Foreign Direct Investment implies that foreign investors who invest their capital should be directly and physically present in running their business. Their investment activities will affect the increasing demand for land. Then, the business entity that will be established will also need land and workers. Therefore, it is necessary to regulate the ownership of the land title which foreigners or foreign legal entities can own. Referring to Articles 42 and 45 of the Law Number 5 year 1960 on Basic Agrarian Principle, it is stipulated that foreigners can only own land with Rights to Use or Leaseholds in Indonesia, provided that it is only for foreigners who are domiciled in Indonesia.

Article 5 of the Government Regulation Number 41 Year 1996 stipulated that the Right to Use can only be granted for 50 (fifty) years, including presenting and renewing. This 
provision is still in line with Government Regulation Number 40 of 1996 Article 45, which said that the period of Rights to Use is not more than 25 (twenty-five) years and can be extended for a maximum of 25 (twenty-five) years while the renewal has not been regulated. Therefore, if accumulated together, land Rights to Use is granted for 50 (fifty) years. The two government regulations contain standard norms and are following the aims and principles of Law Number 5 Year 1960 on Basic Agrarian Principle.

Aceh province could give the assets for the investor for five years only and can be extended with specific requirements. Even though this regulation has been clearly mentioned about the extension of land use for investment, it is not easy to be applied due to long bureaucracy and abundant administration processes that need to be fulfilled. Therefore, according to Edi, as the Agency of Financial Management representative, this regulation needs to be revised because the facts show that many investors face difficulties in extending land Rights to Use. In other words, this regulation does not work correctly and needs to be improved. ${ }^{10}$

Similarly, Marthunis (the head of Aceh Investment and One-Stop Service Agency) said that there are two options regarding the references regulation that can be implemented about the land Rights to Use in Aceh Province. Those are the Regulation of the Minister of Home Affairs Number 19 of 2016 on the Guidelines for the Management of Regional Property or Law Number 5 Year 1960 on Basic Agrarian Principle ${ }^{11}$. Nowadays, the Government used Ministerial Decree, but there are many obstacles occurred. Now the Government is making a new specific law for providing legal certainty in granting land title for investors in Aceh.

\section{CONCLUSION}

It can be concluded that one of the aspects preventing foreign direct investment in Aceh is the regulations regarding the land use license. National rules as described in article 21 of the Law Number 25 Year 2007 facilitate services and /or claims of land title up to 95 years for land Right to Cultivate, up to 160 years for Rights to Build, and up to 140 years for land Rights to Use. Unfortunately, the land title for investors given by the Government of Aceh as stipulated in Article 62(a) of Qanun Number 14 Year 2017 on Aceh's Assets Management is five years and can be extended with specific requirements. This condition

\footnotetext{
${ }^{10}$ Sentosa Sembiring, Hukum Investasi, Bandung: Nuansa Aulia, 2007, p. 3.

${ }^{11}$ Interview with Mr. Marthunis, the head of Aceh Investment and One Stop Services Agency, dated $18^{\text {th }}$ February 2021.
} 
Legal Certainty Of Land Title In Facilitating Foreign Direct Investment

In Aceh Province, Indonesia

Student Journal of International Law

Dina Luqyana, Azhari Yahya

Vol. 1, No. 1, (Agustus, 2021), pp. 48-55.

resulted in less foreign direct investment inflows into Aceh province because of uncertainty

in obtaining the land title for a long time. Therefore, it is suggested that the Government of Aceh should revise the Qanun to be in line with national law Number 25 of 2007. It may create legal certainty in terms of land Rights to Use for foreign investors to invest in Aceh province.

\section{BIBLIOGRAPHY}

\section{Books and Journals}

Aurangzeb Zeb and Thanasis Stengos, "The Role of Foreign Direct Investment (FDI) in a Dualistic Growth Framework: An Application of Smooth Coefficient Semi-parametric Approach." Borsa Instanbul Review, Vol.14, No.3, 2014.

Cep Jandi Anwar, "Faktor-Faktor Yang Mempengaruhi Foreign Direct Investment (Fdi) Di Kawasan Asia Tenggara.", Media Trend, Vol.11, No. 2, 2016.

Claudia TeziaJanuarita Putri and Regina Niken Wilantari, "Determinan Aliran Foreign Direct Investment di Indonesia (Pendekatan Model Dunning).", Media Trend, Vol. 11, No. 2, 2016.

Jaja Ahmad Jayus, "Konsep Sistem Hukum Investasi Dalam Menjamin Adanya Kepastian Hukum.", JURNAL LITIGASI (e-Journal), Vol. 6, No. 2, 2016.

Mario Julyano and Aditya Yuli Sulistyawan, "Pemahaman Terhadap Asas Kepastian Hukum Melalui Konstruksi Penalaran Positivisme Hukum.", Jurnal Crepido, Vol. 1, No. 1, 2019.

Sentosa Sembiring, "Legal Aspect of Foreign Direct Investment in Indonesia Based on the Law of Number 25 of the Year 2017 On Investment.", Sociological Jurisprudence Journal, Vol. 2, No. 1, 2019.

Sentosa Sembiring, Hukum Investasi, Bandung: Nuansa Aulia, 2007.

V. Alecsandru Strat, Adriana Davidescu, and Andreea Maria Paul, "FDI and the unemployment-a causality analysis for the latest EU members.", Procedia Economics and Finance, Vol. 23, No. 2015, 2015.

Ylvije Kraja Boriçi, and Elezi Osmani. "Foreign Direct Investment and Economic Growth in Albania," Economics, Vol 3, No. 2, 2015.

M. Yakub Aiyub Kadir and Alexander Murray, Resource Nationalism in the Law and Policies of Indonesia: A Contest of State, Foreign Investors, and Indigenous Peoples, Asian Journal of International Law, 2019, Vol. 9 (2). 


\section{Law}

Law Number 25 of 2007 On Capital Investment.

Qanun Number 14, Year 2017 about Aceh's Assets Management

\section{Websites}

Investopedia, "Electric Paradigm", <https://www.investopedia.com/terms/e/eclecticparadigm.asp> , [accessed 24/11/2020]

Justin Kuepper, "Foreign Direct Investment", 2019, < https://www.thebalance.com/what-isforeign-direct-investment-1979197>, [accessed 1/3/2020]

Researchconnections, "Field Research", <https://www.researchconnections.org/childcare/datamethods/fieldresearch.jsp>, [accessed 1/12/2020]

Monash University, "Introduction to literature reviews," $<$ https://www.monash.edu/rlo/graduate-research-writing/write-the-thesis/introductionliterature-reviews>, [accessed 4/12/2020]

TPSA Project, "Panduan pengembangan strategi investasi", http://www.tpsaproject.com/wp-content/uploads/2019-02-28-Manual-IDN1124.08c.pdf>, [accessed 15/2/2021] 